\title{
Comparison between 940 nm Laser Diode and Topical $5 \%$ Potassium Nitrate for Tooth Desensitization. Randomized Controlled Clinical trial*
}

Comparación entre el láser diodo de 940 nm y el nitrato de potasio tópico al 5 \% para la desensibilización dental. Estudio clínico controlado aleatorizado

Recibido para publicación: 30-04-2018 | Aceptado para publicación:

\begin{abstract}
OSCAR TOCARRUNCHO
Institución Universitaria Colegios de Colombia UNICOC, Bogotá, Colombia. otocarruncho@unicoc.edu.co. https://orcid.org/0000-0002-5354-5384
\end{abstract}

Xiomara AleXandRa ESPITIA RoBAyo

Institución Universitaria Colegios de Colombia UNICOC, Bogotá, Colombia. xespitia@unicoc.edu.co. https://orcid.org/0000-0002-3632-0239

\begin{abstract}
Edgar Ibáñez Pinilla
Institución Universitaria Colegios de Colombia UNICOC, Bogotá, Colombia. eibanez@unicoc.edu.co. https://orcid.org/0000-0002-1510-0317.
\end{abstract}

\author{
NÉSTOR RAÚl RÍOS-OSORIO ${ }^{\mathrm{a}}$ \\ Institución Universitaria Colegios de Colombia UNICOC, Bogotá, Colombia. \\ nrios@unicoc.edu.co. https://orcid.org/0000-0002-6675-6789
}


*Investigacion original.

a'Correspondencia: $\underline{\text { nrios @ unicoc.edu.co }}$

doi: https://doi.org/10.11144/Javeriana.uo37-79.cldt

Cómo citar: Tocarruncho O, Espitia Robayo XA, Ibáñez Pinilla E, Ríos-Osorio NR. Comparison between $940 \mathrm{~nm}$ laser diode and topical $5 \%$ potassium nitrate for tooth desensitization. Randomized controlled clinical trial. Univ Odontol. 2018 jul-dic; 37(79). https://doi.org/10.11144/Javeriana.uo37-79.cldt

\begin{abstract}
Purpose: To compare the effectiveness of two dental desensitization therapies, 940nm laser diode and potassium nitrate, in patients with dental hypersensitivity (DH) symptoms. Methods: This randomized clinical trial included 30 patients who initially underwent basic periodontal therapy and presented gingival recessions Class I and II (Miller 1985) with symptoms of DH. Subjects were randomly assigned into two groups. The first group $(\mathrm{n}=15)$ received laser $940 \mathrm{~nm}$ application for 90 seconds on the surface of the recession and were given a tube of glycerin to be applied daily in order to avoid generating bias. Patients in the second group $(n=15)$ were exposed to inactive laser simulating the actual application of the laser, and they were given a desensitizing gel containing $0.5 \mathrm{~g}$ of potassium nitrate to be applied twice daily during 14 days. Controls were
\end{abstract}


carried out at 15 minutes, 8 days, 15 days, and 4 weeks. Data obtained were filled out in an Excel table. For comparison between groups the Mann Whitney $U$ and t student tests were used $(\mathrm{p}=0.05)$. Results: All patients involve in the study experienced reduction in $\mathrm{DH}(\mathrm{p}<0.01)$ and differences between the two interventions performed. Conclusions: Laser and nitrate therapies were effective to manage $\mathrm{DH}$ after basic periodontal therapy. However, a statistically significant higher sensitivity reduction was observed in laser therapy group.

\section{Keywords}

diode laser; dentinal sensitivity; potassium nitrate; periodontal disease; gingival recession

\section{Thematic fields}

dentistry; periodontics

\section{RESUMEN}

Objetivo: Comparar la efectividad de las terapias de sensibilización dental que usan láser diodo 940 nm y nitrato de potasio en pacientes con síntomas de hipersensibilidad dental (HD). Métodos: Este ensayo clínico aleatorizado incluyó 30 pacientes quienes habían recibido previamente terapia periodontal básica y presentaban recesiones gingivales clases I y II (Miller 1985) con síntomas de HD. La muestra fue asignada aleatoriamente a los dos grupos. Al primero $(n=15)$ le fue aplicado láser $940 \mathrm{~nm}$ por 90 segundos en la superficie de la recesión, y se les suministró un tubo de glicerina para ser aplicado diariamente y evitar la generación de sesgos. El segundo grupo $(n=15)$ recibió láser inactive como placebo y se le suministró un gel desensibilizante que contenía nitrato 
de potasio 0,5 g para aplicar dos veces al día durante 14 días. Se realizaron controles a los 15 minutos, 8 días, 15 días y 4 semanas. Los datos obtenidos se registraron en una table en Excel. Se emplearon U de Mann Whitney U y t Student para comparar los grupos $(\mathrm{p}=0,05)$. Resultados: Todos los pacientes del estudio mostraron reducción de la $\mathrm{HD}$, diferencias que fueron estadísticamente significativas $(\mathrm{p}<0,01)$ entre los dos grupos intervenidos. Conclusiones: Ambos, el láser diodo y el nitrato fueron efectivos en el manejo posterior a la terapia periodontal para el manejo de la HD. Sin embargo, las diferencias fueron mayores para el grupo de terapia con láser.

\section{Palabras clave}

enfermedades periodontales; láser diodo; nitrato de potasio; recesión gingival; sensibilidad dentinal

\section{Áreas temáticas}

odontología; periodoncia

\section{INTRODUCTION}

Non-surgical periodontal therapy refers to the conventional and conservative way of removing supra and subgingival bacterial plaque and calculus in order to establish and maintain healthy periodontal tissues by removing irritants from the tooth surfaces which promote plaque retention (1). Nevertheless, patients undergoing periodontal therapy often report experiencing discomfort in the form of dentinal hypersensitivity (DH), characterized by a short sharp pain that can be explained by the theory proposed by Brännström in 1966, which propound that a stimulus-induced 
shift in the movement of the intratubular fluid (either inward or outward) can activate pulpal nociceptor, resulting in pain $(2,3)$.

Within the etiological entities and procedures related to $\mathrm{DH}$, it is notorious the high incidence of scaling and root planning therapy with or without surgical technique; as a result of the apical migration of the gingival margin and the consequent root exposure accompanied by the removal of dental tissue subsequent to the periodontal therapy, where dentinal tubules possibly get exposed, so that the patients generally show acute and localized pain in response to mechanical, thermal ,osmotic and chemical stimuli (4).

Dentinal hypersensitivity appears to be a common condition. Several Epidemiological studies carried out in different countries, along different periods of time, have indicated an incidence ranging between 4 to $74 \%$ of $\mathrm{DH}$ among the studied population. Teeth with the highest incidence of $\mathrm{DH}$, are the upper premolars followed by the maxillary molars; a higher incidence is also observed in females compared to males, which is not statistically significant (5-12). However, currently, the scientific literature exposes great discrepancy among these types of studies, on account of the non-standardization of the diagnostic procedures, thus creating wide discrepancies among results due to the large number of non-controlled variables such as: degree of gingival recession, smoking and periodontal disease diagnosis that can arise and can influence these diagnoses itself.

According to Brännström's theory (1966), the main strategy for the treatment of DH would consists of sealing the dentinal tubules, hence preventing fluid flow movement. Therefore, any 
treatment modality that can block or reduce the movement, blocks the pain transmission, or occludes the dentinal tubule and precipitates proteins can prove beneficial in the treatment of DH $(2,13)$.

At date, several strategies such as therapeutic toothpaste containing fluorides and nitrates, desensitizing topical agents (fluoride salts, potassium nitrate (KNO3), oxalate, calcium phosphate, and arginine), iontophoresis, adhesives, resins, and lasers have been tried to mitigate symptoms $(14,15)$. Potassium nitrate $(\mathrm{KNO} 3)$ for topical use is one of the most popular precipitating substances used for blocking dentinal tubes. The mechanism of action of potassium nitrate is largely unknown, although an oxidizing effect or blocking of tubules by crystallization has been proposed (16). Other authors posit that Potassium ion tends to accumulate in dentinal tubules leading to depolarization of cellular membrane of terminal nerve endings thus greatly reducing sensitivity (17). In addition, topical application therapy of Potassium nitrate is considered a technique of easy application, optimal manipulation and low costs. However, the main disadvantage related to this kind of treatment is the patient constancy along treatment, since immediate effects are not seen, and, in many cases, there is a recurrence of hypersensitivity upon the withdrawal of the product (14).

On the other hand, laser technology has been studied widely for treating DH since the mid-1980s though results were divergent (15). The neodymium-doped: yttrium, aluminum and garnet (Nd:YAG), CO2 and yttrium, aluminum and garnet (Er:YAG) lasers , have been the most widely used, because of their property of causing melting and resolidification of superficial dentin, its thermos mechanical ablation mechanism and the high absorption of its wavelength by water (18- 
21). More recently, especially over the last decade, a new tendency in laser therapy termed Lowlevel lasers, mostly oriented upon the therapeutic, rather than the surgical applications, has been developed. Low-level laser therapy (LLLT) provides cold thermal low energy wavelengths (400$900 \mathrm{~nm}$ ) triggering a non-thermal bio activation at the periphery of the target tissues with biostimulatory and bio -modulatory effects (22-24). LLLT as an alternative for the management of hypersensitivity has proven to produce an immediate analgesic effect, due to a photo-bio modulation on the dental pulp which increases and regulates the metabolic and the cellular activity (25).

Recent studies have reported good results when using Low-Level Laser Therapy in Reducing DH and Pain. However, the scientific literature remains ambiguous in terms of predictability and efficacy of these treatments, and further studies are required to support such results. Moreover, a Cochrane Database Systematic Review failed to find strong evidence supporting the efficacy of potassium nitrate toothpaste for dentine hypersensitivity (26).

In view of the foregoing, the main objective of this study was to evaluate and compare the application of diode laser $940 \mathrm{Nm}$ vs $5 \%$ potassium nitrate as potential treatments for dentin hypersensitivity (DH).

\section{MATERIALS AND METHODS}

A randomized clinical trial was performed according to the resolution 8430 from the Colombian Ministry of Health regarding ethical issues in research involving human tissues and was approved 
by the bioethics committee of the University Colegios de Colombia (UNICOC). The informed consent of all human subjects who participated in the experimental investigation was obtained before the nature of the procedure and possible discomforts and risks had been fully explained.

30 patients (23 females and 7 males) attending the Department of Periodontology seeking periodontal maintenance treatments at the UNICOC dental clinics, who met the inclusion criteria: Patients aged 18-65 years, were selected for the study.

Inclusion criteria: 1) Previously diagnosed with severe; (2) Moderate and mild chronic periodontitis; 3) Gingival recessions greater than $2 \mathrm{~mm}$; 4) Report of dental sensitivity after receiving periodontal treatment.

Exclusion criteria: 1) Being Pregnancy or lactating; 2) reported hypersensitivity to the study components; 3) patients using some treatment for hypersensitivity within the last 30 days prior to the study; 4) caries; 5) Subgingival restorations; 6) pulp pathologies; 7) smoking; 8) uncontrolled systemic diseases; 9) usage of analgesic, anticonvulsants, sedatives, tranquilizers, and anti-inflammatory drugs within $72 \mathrm{~h}$. The purpose and design of the investigation were explained to patients and an informed consent form was signed.

Thirty transparent plastic bags marked with the letter A (glycerin-laser diode 940nm active) and B (Potassium Nitrate $5 \%$-inactive laser) were randomly distributed among the patients by choosing a ballot with the corresponding letter (A or B), containing an envelope with the informed consent, 
the collection instrument and indications for use of The gels according to group (A or B), and a tube with no description of its content ( $5 \%$ of potassium nitrate or placebo glycerin gels).

For assessing the pain expressed by the patients, before and after treatment, the verbal rating scale (VRS) was used. VRS is a four-point scale where $0=$ no pain, discomfort, $1=$ mild pain/discomfort, $2=$ marked pain/discomfort during the application of the stimulus, $3=$ marked pain/discomfort lasting for $>10 \mathrm{sec}$ was also used after withdrawal of the stimulus.

Two test sites (teeth surface) with gingival recession and dental sensitivity and the highest VSR were selected in each patient for receiving either laser irradiation (group A) or desensitizing gel therapy (group B).

Group A $(n=15)$, Previous cleaning of the tooth surface (test site) with cotton, patients were subjected to irradiation treatment in a single session with surface contact, through a laser diode with a wave-length of $940 \mathrm{~nm}$, and the average output power of 0.8 to 1.0 , Watt, for 60 to 150 seconds. Directions, for glycerin application at home were given. Briefly, patients were instructed to apply the gel twist a day for 14 days on the teeth surface, left it for 3 minutes and wash.

Group B ( $n=15)$ Application of gel containing 5\% Potassium Nitrate was performed on the surface of the teeth and left for 3 minutes, the surface was then washed and laser irradiation was performed in a single session, using a wavelength of $940 \mathrm{~nm}$, at an output power of 0.8 to 1.0 Watt for 60 to 150 seconds (the laser was used as a placebo, although it was placed and used in a similar 
fashion, it was not activated).Indications for application of Nitrate gel twist a day for 14 days were given.

In accordance with consensus guidelines two independent stimulus-based clinical measures were used to assess DH (evaporative and tactile stimulus) (27).

First evaporative (air)sensitivity control (T1) was performed 15 minutes after the procedure on each selected tooth (tooth 1 and tooth 2); tactile sensitivity was also carried out during all controls. Second control at 8 days (T2), third control at 15 days (T3), fourth control at month (T4); the VRS test was used for assessing the results at both stimulus (evaporative and tactile).

Evaluation of evaporative (air) sensitivity reported on the selected teeth (test sites) was performed before treatment (Basal Characteristics), at T1, T2, T3 and T4 on each patient: The VRS was measured by isolating the selected tooth with a cotton swab and applying an air blast using an air syringe from a distance of $1 \mathrm{~cm}$ per 1 second, as reported by Tarbert et al., 1979 and Collins et al., 1984 (28).

Sensitivity to mechanical stimulus (tactile stimulus) was measured by scraping the exposed root surface (test sites) of the teeth by means of a North Carolina periodontal prove(PCP) as described by Collins et al. 1984, Silverman 1986. The patient's response was classified according to the above-mentioned VSR scale (29). 
The commitment degree with the treatment was evaluated by measuring the weight of the tube of bioadhesive gel returned by the patient at the control on day 15 , according to the following table: Correct (acceptable): gel consumption of approximately 80-100\% of the supply, regular (acceptable): consumption of approximately 60-80 \% of gel supply and Insufficient (unacceptable): gel consumption of $0-60 \%$ of the amount provided.

Patients were advised not to use fluoride toothpaste when brushing, and to use the delivered gels as recommended, as well as indications of oral hygiene, avoiding aggressive cleaning habits, were given a soft toothbrush on the day of the test and avoided the use of any desensitizing toothpaste.

\section{Statistical analysis}

$\mathrm{R}$ statistical program was digitized and debugged. For comparison between groups the Mann Whitney U test was used, the significance was $5 \%$.

\section{RESULTS}

30 patients sample, distributed into two groups A (glycerin-laser diode $940 \mathrm{~nm}$ active) and B (Potassium Nitrate 5\% inactive laser), 15 patients in each group were used for this study.

Basal Characteristics: Regarding the groups, no statistical differences were found between them (table 1). At all times, there were statistically significant differences $(\mathrm{p}<0.01)$ in the mechanical sensitivity between the laser and Nitrate groups, with a higher sensitivity observed in the Nitrate group (table 2, figure 1). 
Statistically significant differences $(\mathrm{p}<0.01)$ in thermal sensitivity between laser and Nitrate groups were found at all times, with higher sensitivity in Nitrate group (table 3, figure 2).

TABLE 1

BASELINE CHARACTERISTICS BETWEEN GROUPS

\begin{tabular}{lccccc}
\hline \multirow{2}{*}{ Variables } & \multicolumn{2}{c}{ Laser } & \multicolumn{2}{c}{ Nitrate } & p value \\
\cline { 2 - 5 } & mean(s.d) & Median & mean(s.d) & Median & 0,671 \\
\hline Age & $38,2(8,3)$ & 39 & $36,93(7,91)$ & 36 & 0,679 \\
$\begin{array}{l}\text { Gender(F) } \\
\begin{array}{l}\text { Evaporative } \\
\text { sensitivity }\end{array}\end{array}$ & $2,43(0,4169)$ & 2,5 & $2,53(0,352)$ & 2,5 & 0,464 \\
$\begin{array}{l}\text { Tactile } \\
\text { sensitivity }\end{array}$ & $2,13(0,581)$ & 2 & $1,6(0,712)$ & 2 & 0,053 \\
\hline
\end{tabular}

TABLE 2

MECHANICAL SENSITIVITY BETWEEN LASER AND NITRATE

\begin{tabular}{llclccccc}
\hline \multicolumn{1}{c}{ Laser } & \multicolumn{7}{c}{ Nitrate } \\
\hline Tooth & Time & Mean & s.d & Median & Mean & s.d & Median & p value \\
$1-2$ & 15 minutes & 0,23 & 0,372 & 0 & 1,47 & 0,790 & 1,5 & $0 * *$ \\
$1-2$ & 8 days & 0,17 & 0,309 & 0 & 1,07 & 0,678 & 1,00 & $0,001 * *$ \\
$1-2$ & 15 days & 0,13 & 0,297 & 0 & 0,93 & 0,678 & 1,00 & $0,002 * *$ \\
$1-2$ & 1 Month & 0,77 & 0,188 & 0 & 0,92 & 0,703 & 1,00 & $0,001 * *$ \\
\hline$* \mathrm{p}<0,05$ & $* * \mathrm{p}<0,01$ & & & & & & &
\end{tabular}


TABLE 3

EVAPORATIVE (AIR) SENSITIVITY BETWEEN LASER AND NITRATE

\begin{tabular}{|c|c|c|c|c|c|c|c|c|}
\hline \multirow[b]{2}{*}{ Tooth } & \multirow[b]{2}{*}{ Time } & \multicolumn{3}{|c|}{ Laser } & \multicolumn{2}{|c|}{ Nitrate } & \multirow[b]{2}{*}{ Median } & \multirow{2}{*}{$P$ value } \\
\hline & & Mean & s.d & Median & Mean & s.d & & \\
\hline $1 \mathrm{y} 2$ & 15 minutes & 0,80 & 0,775 & 1 & 2,10 & 0,632 & 2 & $0 * *$ \\
\hline $1 \mathrm{y} 2$ & 8 days & 0,50 & 0,681 & 0,5 & 1,73 & 0,530 & 2 & $0 * *$ \\
\hline $1 \mathrm{y} 2$ & 15 days & 0,47 & 0,481 & 0,5 & 1,80 & 0,592 & 2 & $0 * *$ \\
\hline $1 \mathrm{y} 2$ & 1 Month & 0,50 & 0,456 & 0,5 & 1,96 & 0,691 & 2 & $0 * *$ \\
\hline
\end{tabular}

FIGURE 1

BOX PLOTS FOR TIME AND INTERVENTION "EVAPORATIVE STIMULUS"

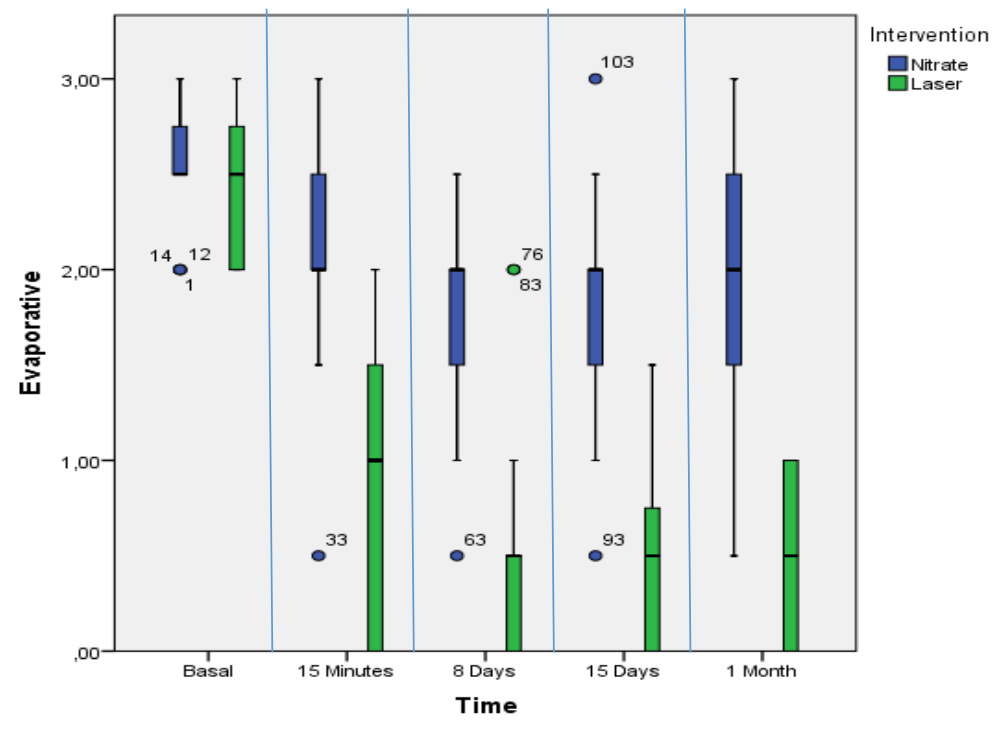

FIGURE 2

BOX PLOTS FOR TIME AND INTERVENTION "MECHANICAL STIMULUS"

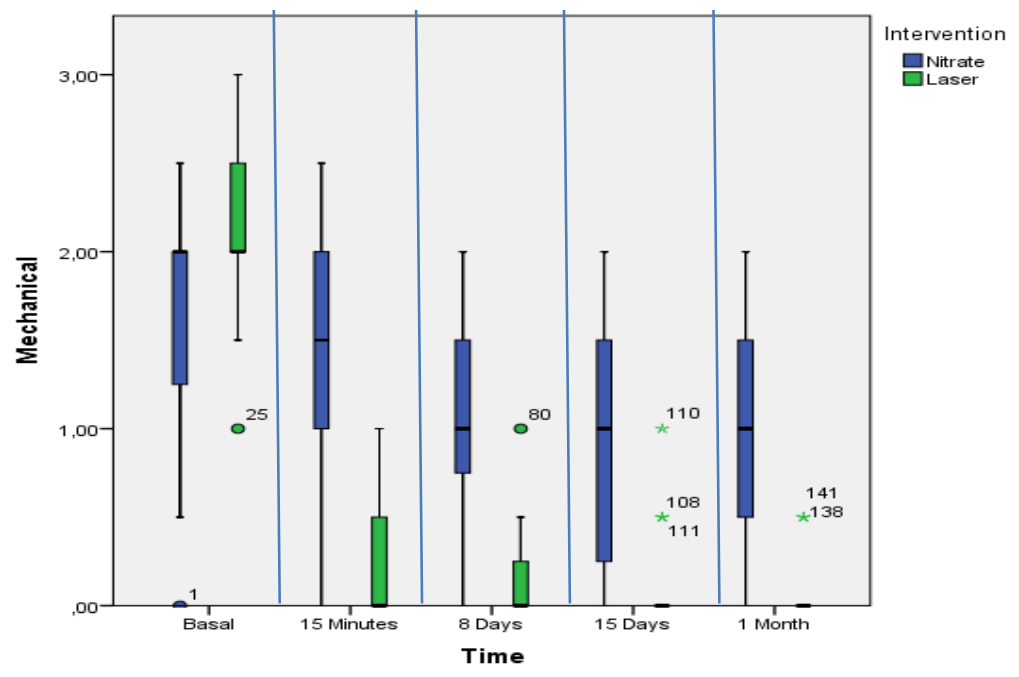




\section{DISCUSSION}

Postoperative DH is one of the most frequent complaints following periodontal therapy, with a reported prevalence ranging from 76.8-80.4\% after 1 day to and $21.7 \%$ after 8 weeks $(30,31)$.

The clinical efficacy of a wide range of products and therapies for $\mathrm{DH}$ relief has been examined in numerous clinical studies with a variety of designs, largely based on standard 'guidelines' since 1997 (27). However even though currently the physiological basis of the DH is quite clear, treatment results for the management of dentinal hypersensitivity are not completely predictable (14). The present study aimed at comparing the efficacy of desensitizing treatment with diode laser 940nm vs Potassium Nitrate 5\%, in patients with symptoms of dentinal hypersensitivity after periodontal therapy showing that LLLT, has given better results when compared to the use of KNO3 ( $<<0.05)$, immediately and within a short term follow up after periodontal therapy, making it a suitable approach to the treatment of $\mathrm{DH}$.

When the values obtained by each of the therapies were individually observed, it was evident that for the potassium nitrate group, the results obtained in terms of desensitization took place gradually, while with the use of LLLT, values were generated immediately and lasted along the full follow up (30 days).

The advent of dental lasers has risen as another option for the treatment of DH. The reduction in DH by LLLT has been attributed to its property of increasing cellular activity thus boosting the production of mitochondrial ATP, and the ability of providing an analgesic effect by acting at 
membrane $\mathrm{Ca}$ channels, increasing the threshold of the free nerve endings and the depolarization of $\mathrm{C}$ fiber afferents which is believed to block the transmission of pain stimuli in hypersensitive dentin. Moreover, laser effects on endorphin release could be the reason for the immediate pain relief in patients. LLLT IS also believed to increase formation of the secondary dentin by odontoblasts in the process of bio stimulation (32-36).

In a similar study, Akca et al. (2006) assessed the effectiveness of 1'40 minutes' low-power laser irradiation $(685 \mathrm{~nm}, 25 \mathrm{~mW}, 2 \mathrm{j} / \mathrm{cm} 2)$ in hypersensitive teeth. After desensitization by LLLT , most patients reported different reductions levels in $\mathrm{DH}$, when tested by applying an air blast using an air syringe and qualifying by using visual analogue scale (VAS); which verified the effectiveness of the LLLT; in addition, statistical analysis indicated that an air-jet stimulus was a more reliable method than the tactile stimuli at testing dentin hypersensitivity (37). Similar results from a parallel study design were reported by George et al. (2016), who evaluated a $810 \mathrm{~nm}$ diode laser at managing of $\mathrm{DH}$, using an evaporative and a tactile stimulus, whose results indicated that significant differences were generated from the baseline to the end of the study (day 30) for the measured parameters, revealing the effectiveness of laser therapy (38).

Umberto et al. (2012), using a Gallium-Aluminum-Arsenide (GaAlAs) diode laser carried out a dental desensitization study, were included 10 patients $(8 \mathrm{~F} / 2 \mathrm{M}, 25-60$ years) and $115 \mathrm{DH}$ teeth evaluated by air and tactile stimuli measured with the Numerical Scale (NRS). Results from this study showed a significant reduction of pain $(\mathrm{p}<0.001)$, for both air and tactile stimuli; which helped them to conclude that the diode laser is a useful device for the treatment of DH when used alone but has better results when combined with a gel (39). 
Result from our study show that the use of LLLT has played a beneficial role in diminishing DH level which are in accordance with the results mentioned above and as previously also reported by Yamaguchi et al. 1990; Groth. 1993; Gershman et al.1994, Yui et al. 2003 and Pandey R, et al. 2017 (40-44).

Contrasting results were shown in Vieira et al. study in which diode laser with placebo oxalate gel,

placebo laser along with oxalate gel, and placebo oxalate and placebo laser were compared; did not show any significant differences in reduction of sensitivity after 3 months follow-up (45).

\section{CONCLUSIONS}

$940 \mathrm{~nm}$ diode laser therapy may be considered as a therapeutic alternative for the management of dentinal hypersensitivity.

Immediate effects of diode laser therapy were observed compared to the gradual effect of daily use of potassium nitrate.

A trained operator is required for the correct use of the laser, due to the various variables that may have depending on the type of laser and its wavelength. 
More longitudinal studies are required with greater follow-up, in order to establish a protocol, where it is possible to determine the number of laser applications or combinations between conventional and laser therapies, to achieve a greater therapeutic effect.

To validate the present study results long-term studies with bigger sample size are needed.

\section{ACKNOWLEDGEMENTS}

The authors declare that they have no conflict of interest.

A randomized clinical trial was performed and classified as "Investigations with risk greater than the minimum" according to the resolution 8430 from the Colombian Ministry of Health regarding ethical issues in research involving human tissues and was approved by the bioethics committee

of the University Colegios de Colombia (UNICOC). The informed consent of all human subjects who participated in the experimental investigation was obtained before the nature of the procedure and possible discomforts and risks had been fully explained.

The authors affirm to have no financial affiliation (e.g., employment, direct payment, stock holdings, retainers, consultantships, patent licensing arrangements, or honoraria) or involvement with any commercial organization with direct financial interest in the subject or materials discussed in this manuscript.

\section{REFERENCES}


1. Greenstein G (2000) Nonsurgical periodontal therapy in 2000: A literature review. J Am Dent Assoc. 13:1580-92

2. Brännström M (1966) Sensitivity of dentine. Oral Surg Oral Med Oral Pathol 21:517-526

3. Petersilka, G. J., Ehmke, B., \& Flemmig, T. F (2002) Antimicrobial effects of mechanical debridement. Periodontology 2000. 28 (1): 56-71

4. Ady M (2002). Dentine hypersensivity. New perspectives and old problem. Inter Dent J. 52: $367-78$

5. Bartold, P. M. (2006) Dentinal hypersensitivity: a review. Australian dental journal 51(3): 212218

6. Fischer C, Fischer RG, Wennberg A. (1992) Prevalence and distribution of cervical dentine hypersensitivity in a population in Rio de Janeiro, Brazil. J Dent 20:272-276

7. Rees JS, Addy M. (2002) A cross-sectional study of dentin hypersensitivity. J Clin Periodontol 29:997-1003

8. Flynn J, Galloway R, Orchardson R. (1985) The incidence of "hypersensitive "teeth in the west of Scotland. J Dent 13:230-236

9. Jensen AL. (1964) Hypersensitivity controlled by iontophoresis: double-blind clinical investigation. J Am Dent Assoc 68:216-225.

10. Graf H, Galasse R. (1997) Morbidity, prevalence and intraoral distribution of hypersensitive teeth (Abstract No. 479). J Dent Res 56(Spec Iss A):162.

11. Murray LE, Roberts AJ. (1994) The prevalence of self-reported hypersensitive teeth. Arch Oral Biol 39:129S. 
12. Liu HC, Lan WH, Hsieh CC. (1998) Prevalence and distribution of cervical dentin hypersensitivity in a population in Taipei, Taiwan. J Endod 24:45-47

13. Orchardson R, Gillam DG (2006) Managing dentin hypersensitivity. J Am Dent Assoc 137:990-8-9

14. Trushkowsky R, Oquendo A. (2011) Treatment of dentine hypersensitivity. Dental Clinics of North America July 55 (3): 599-608

15. Sgolastra F, Petrucci A, Gatto R, Monaco A. (2011) Effectiveness of laser in dentinal hypersensitivity treatment: A systematic review. J Endod 37:297-303

16. Hodosh M. (1974) A superior desensitizer - potassium nitrate. J Am Dent Assoc 88:831-832

17. Pashley DH, O’Meara JA, Kepler EE, Galloway SE, Thompson SM, Stewart FP.(1984) Dentin permeability. Effects of desensitizing dentifrices in vitro. J Periodontol 55:522-5

18. Pick, R.M., Pecaro, B.C., and Silberman, C.J. (1985). The laser gingivectomy: the use of CO2 laser for removal of phenytoin hyperplasia. J. Periodontol. 56, 492-496

19. White, J.M., Goodis, H.E. and Rose, C.L. (1987). Use of the pulsed Nd:YAG laser for intraoral soft tissue surgery. Lasers Surg. Med. 7, 207-213

20. Midda, M. (1992). The use of lasers in periodontology. Curr. Opin. in Dent. 2, 104-108

21. Aoki, A., Ando, A., Watanabe, H., and Ishikawa, I. (1996). In vitro studies on laser scaling of subgingival calculus with an Er:YAG laser. J. Periodontol. 65, 1097-1106

22. Asnaashari, M., and Moeini, M. (2013). Effectiveness of lasers in the treatment of dentin hypersensitivity. J. Lasers Med Sci 4.1, 1-7

23. Sun, G., and Tuner, J. Low-level laser therapy in dentistry. (2004). Dent. Clin. North Am. 48, $1061-1076$ 
24. Posten, W., Wrone, D.A., Dover, J.S., Arndt, K.A., Silapunt, S., and Alam, M. (2005). Low level laser therapy for wound healing: mechanism and efficacy. Dermatol. Surg.31, 334-340

25. Brugnera Júnior A, Zanin F, Pinheiro A, Pécora J, Ladalardo TC, Campos D, Garrini, A, Donamaria E, Cruz F, Takamoto M. LLLT in treating dentinary hypersensibility: a histologic study and clinical application. Second International Conference on Near-Field Optical Analysis: Photodynamic Therapy \& Photobiology Effects Houston, Texas, USA, May 31 June 1, 2001. Proceedings of the Second International Conference on NOA, 2002: 23-31

26. Poulsen S, Errboe M, Hovgaard O, Worthington HW. (2001) Potassium nitrate toothpaste for dentine hypersensitivity. Cochrane Database Syst Rev 2:CD001476

27. Holland G.R., Narhi M.N., Addy M., Gangarosa L., and Orchardson R. (1997) Guidelines for the design and conduct of clinical trials on dentine hypersensitivity. J. Clin. Periodontol. 24: pp. $808-813$

28. Collins SL, Moore RA \& McQuay HJ.(1997) The visual analogue pain intensity scale: what is moderate pain in millimeters? Pain ; 72:95-97

29. Hjermstad, Marianne Jensen et al. Studies Comparing Numerical Rating Scales, Verbal Rating Scales, and Visual Analogue Scales for Assessment of Pain Intensity in Adults: A Systematic Literature Review. Journal of Pain and Symptom Management, 2011; 41(6): 1073 - 1093

30. Canakci, C.F., and Canakci, V. (2007). Pain experienced by patients undergoing different periodontal therapies. J. Am. Dent. Assoc. 138, 1563-1573.

31. Lin, Y.H., Gillam, D.G. (2012). The prevalence of root sensitivity following periodontal therapy: a systematic review. Int. J. Dent. 12 pp. 407023

32. Yui KCK, Jorge ALC, Gonçalves SEP, Rodrigues JR, Nicoló DR.(2003) Low level laser therapy for dentine hypersensitivity. Braz Oral Res 6: 17-24. 
33. Gerschman, J.A., Ruben, J., and Gebart-Eaglamont, J. (1994) Low level laser therapy for dentinal tooth hypersensitivity. Aust Dent. J 39.6, 353-357

34. Corona, S.A., Nascimento, T.N, Catirse, A.B., Lizarelli, R.F., Dinelli, W., and Palma-Dibb, R.G. (2003). Clinical evaluation of low-level laser therapy and fluoride varnish for treating cervical dentinal hypersensitivity. J. Oral Rehabil. 30, 1183-1189.

35. Byrnes, K.R., Tsuchyia, K., Rochkind, S. (2002). Cellular invasion following spinal cord lesion and low power laser irradiation. Lasers Surg. Med. S14:11.

36. Marsilio, A.L., Rodrigues, J.R., and Borges, A.B. (2003). Effect of the clinical application of the GaAlAs laser in the treatment of dentine hypersensitivity. J. Clin. Laser Med. Surg. 21.5, $291-296$

37. Akca AE, Gökce S, Kürkcü M, Özdemir A. (2006) A clinical investigation of low-level laser irradiation on hypersensitive dentine. Hacettepe Dişhekimliği Fakültesi Dergisi, 30 (2): $94-99$

38. George VT, Mathew TA, George N, John S, Prakash SM, Vaseem MS. (2016) Efficacy of diode laser in the management of dentin hypersensitivity following periodontal surgery. Journal of International Oral Health, 8 (1): 103-108

39. Umberto R, Russo C, Palaia G, Tenore G, Del Vecchio A. (2012)Treatment of Dentine Hypersensitivity by Diode Laser: A Clinical Study. International Journal of Dentistry, DOI:10.1155/2012/858950

40. Yamaguchi M, Ito M, Miwata T. (1990) Clinical study on the treatment of hypersensitive dentin by GaAlAs laser diode using double blind test. Aichi Gakuin Daigaku Shigakkai Shi 28 (2): 703-7. 
41. Groth E.B. Contribuição para o estudo da aplicação de laser de baixa potência de GaAlAs no tratamento da hipersensibilidade dentinária. São Paulo; 1993. [Dissertação de Mestrado em Dentística - Faculdade de Odontologia da Universidade de São Paulo]

42. Gerschman JA, Ruben J, Gebart-Eaglemont J.(1994) Low level laser therapy for dentinal tooth hypersensitivity. Aust Dent J 39 (6): 353-7.

43. Orhan K, Aksoy U, Can-Karabulut DC, Kalender A.(2011) low level laser therapy for dentine hypersensitivity. Lasers Med Sci. Sep; 26(5):591-8

44. Pandey, R; et al.(2017) Treatment of dentinal hypersensitivity using low-level laser therapy and 5\% potassium nitrate: a randomized, controlled, three arm parallel clinical study. International journal of applied \& basic medical research. 7,1, 63-66.

45. Vieira AH, Passos VF, de Assis JS, Mendonça JS, Santiago SL. (2009) Clinical evaluation of a $3 \%$ potassium oxalate gel and a GaAlAs laser for the treatment of dentinal hypersensitivity. Photomed Laser Surg 27:807-12. 